\title{
MEMBERSHIP LIST
}

OF THE

\section{AMERICAN MATHEMATICAL SOCIETY}

The address list of the members of the American Mathematical Society is available at the prices indicated below to business firms, publishing houses, and other institutions. However, the purposes for which the list is desired must in any instance be consonant with the aims and functions of the Society, and lists will be furnished only to applicants who meet this criterion.

A typical example of an acceptable purpose would be to announce a new mathematical publication considered to be of rather broad interest to the membership of the Society.

Commercial firms are urged to consider as an alternative or supplement to direct mailing to the membership, the possibility of advertising in the Combined Membership List (an annual directory of the Society and related organizations), or in the Bulletin of the American Mathematical Society and Mathematical Reviews. The Bulletin reaches the entire membership six times a year. Advertising rates for these publications will be sent on request.

The complete address list is alphabetized within various geographically defined sections. Such sections may be ordered separately. There is no straight-through non-geographic alphabetized mailing list available. In general, domestic geographic sections follow state boundaries, with major cities set off within the states. Foreign geographic sections follow national boundaries.

\section{PRICES}

1. Entire address list, or geographical sections thereof, on standard unperforated $31 / 2$ " paper tape, ungummed, for use with dick mailer, $\$ 12.00$ per 1,000 names. (The entire membership currently numbers about 5,000.)

2. Same, on envelopes to be supplied by applicant, $\$ 18.00$ per 1,000 names.

Note: There will automatically be a $50 \%$ reduction to the collegiate presses of colleges and universities which are institutional members of the Society, and to other non-profit activities conducted by institutional members. A similar automatic reduction will be given to corporate members. Also, from time to time, certain worthy foreign publication projects will be declared eligible for the reduced rate for a single mailing list.

Requests for the address list should be sent to the Executive Director, American Mathematical Society, 80 Waterman Street, Providence 6, Rhode Island. 


\section{American Mathematical Society}

\section{Bulletin of the American Mathematical Society}

This journal is the official organ of the Society. It reports official acts of the Society and the details of its meetings, with abstracts of all research papers presented. It contains some of the officially invited addresses presented before the Society, and reviews of advanced mathematical books.

The subscription price is $\$ 7.00$ per annual volume of six numbers.

Invited addresses offered for publication should be sent to G. B. PRICE, 215 Strong Hall, University of Kansas, Lawrence, Kan.; research problems to W. T. MaRTIN, Room 2-255, Massachusetts Institute of Technology, Cambridge 39, Mass.; book reviews to J. C. Oxтовy, Bryn Mawr College, Bryn Mawr, Pa. All other communications to the editors should be addressed to the Managing Editor, W. T. MARTIN.

\section{Proceedings of the American Mathematical Society}

This journal is devoted entirely to research in pure and applied mathematics and is devoted principally to the publication of original papers of moderate length.

The subscription price is $\$ 11.00$ per annual volume of six numbers.

Papers in algebra, number theory, logic and foundations should be sent to RICHARD Brauer, 2 Divinity Avenue, Harvard University, Cambridge 38, Mass.; in geometry and topology to S. S. CHERN, Department of Mathematics, University of Chicago, Chicago 37, Ill.; in probability, real variables, and abstract analysis to SHIzUo Kakutani, Leet Oliver Memorial Hall, Yale University, New Haven 11, Conn.; in other branches of analysis, applied mathematics, and all other fields to R. P. BoAs, Lunt Building, Northwestern University, Evanston, Ill. All other communications to the editors should be addressed to the Managing Editor, RICHARD BRAUER.

\section{Transactions of the American Mathematical Society}

This journal is devoted entirely to research in pure and applied mathematics, and includes in general longer papers than the ProceEdings.

Three volumes of two numbers each will be published in 1956. The subscription price is $\$ 6.00$ per volume.

Papers in geometry should be sent to Herbert Busemann, University of Southern California, Los Angeles 7, Calif.; in algebra and number theory to A. H. Clifford, Newcomb College, Tulane University, New Orleans 18, La. (during the summer to the Providence office of the Society); in analysis and applied mathematics to Professor Mark Kac, White Hall, Cornell University, Ithaca, New York; in topology, logic and foundations to W. S. Massey, Department of Mathematics, Brown University, Providence 12, R. I. All other communications to the editors should be addressed to the Managing Editor, W. S. Massey.

\section{Memoirs of the American Mathematical Society}

This series is devoted to the publication of research monographs in pure and applied mathematics. The memoirs are issued serially, but not periodically. Each issue consists of either a single monograph or a group of cognate papers and is priced separately according to size and cost of publication. The editorial standards for acceptance are the same as for the TRANSACTIONS and manuscripts intended for publication should be submitted to the appropriate editor of the TRANSACTIONS. All other communications to the editors should be addressed to HERBERT BUSEMANN.

\section{Mathematical Reviews}

This journal contains abstracts and reviews of the current mathematical literature of the world. It is sponsored by thirteen mathematical organizations, located both in the United States and abroad.

MATHEMatical Reviews is published monthly, excepting July. The subscription price is $\$ 20.00$ per annual volume of eleven numbers. 


\section{OFFICIAL COMMUNICATIONS}

\section{Meetings of the Society}

Abstracts for all meetings of the Society should be sent to the American Mathematical Society, 190 Hope St., Providence 6, R. I.

Cambridge, Massachusetts, October 27, 1956.

Abstracts must be received not later than September 13. By invitation of the Committee to Select Hour Speakers for Eastern Sectional Meetings, there will be an address by J.-P. Serre entitled Covering of algebraic varieties.

Pasadena, California, November 17, 1956.

Abstracts must be received not later than October 4. By invitation of the Committee to Select Hour Speakers for Far Western Sectional Meetings, there will be an address by Professor Bertram Yood entitled Semi-simple Banach algebras.

Evanston, Illinois, November 23-24, 1956.

Abstracts must be received not later than October 4. By invitation of the Committee to Select Hour Speakers for Western Sectional Meetings, there will be an address by Professor George Piranian.

Lexington, Kentucky, November 30-December 1, 1956.

Abstracts must be received not later than October 4. By invitation of the Committee to Select Hour Speakers for Southeastern Sectional Meetings there will be an address by Professor O. G. Harrold, Jr.

Annual Meeting, Rochester, New York, December 27-29, 1956.

Abstracts must be received not later than November 13. The Gibbs Lecture will be delivered by Professor M. H. Stone.

New York, New York, April 5-6, 1957.

Abstracts must be received not later than February 20.

Summer Meeting, University Park, Pennsylvania, August 2630, 1957.

Abstracts must be received not later than July 12.

Washington, D. C., October 26, 1957.

Abstracts must be received not later than September 12 .

E. G. Begle, Secretary of the Society 